\title{
Simultaneity and aggregation of risk factors for noncommunicable diseases among brazilian adolescents ${ }^{\circ}$
}

\author{
Simultaneidade e agregamento de fatores de risco para doenças crônicas não transmissíveis em \\ adolescentes brasileiros
}

\section{Simultaneidad y agregación de factores de riesgo para enfermedad crónicas no transmisibles en adolescentes brasileños}

\section{Fabiana Lucena Rocha ${ }^{1}$ Gustavo Velasquez-Melendez ${ }^{2}$ (1)}

1. Universidade Federal de Campina Grande. Cajazeiras, PB, Brasil.

2. Universidade Federal de Minas Gerais. Belo Horizonte, MG, Brasil.
Corresponding author:

Fabiana Lucena Rocha.

E-mail: fabiana.rocha@ufcg.edu.br

Submitted on $10 / 29 / 2018$.

Accepted on 04/18/2019.

DOI: 10.1590/2177-9465-EAN-2018-0320

\begin{abstract}
Objective: To estimate the prevalence of concurrency of risk factors for Noncommunicable Diseases and non-random aggregation of these in Brazilian school adolescents. Method: Descriptive study, with data from the National School Health Survey (Pesquisa Nacional de Saúde do Escolar), 2015. The prevalence of concurrent risk factors was estimated: smoking, alcohol use, physical inactivity and low consumption of fruits and vegetables. Aggregation was verified when the observed-expected prevalence ratio was greater than 1. The analyses were performed in Stata 15.0 software. Results: The proportion of concurrent risk factors was higher for those who had two risk factors $(56.1 \%$; $95 \% \mathrm{Cl}$ : 55.5-56.6). The most prevalent risk factors combination was "Low consumption of fruits and vegetables + Physical inactivity" (66\%; 95\% Cl: 65.8-66.9). There was an aggregation of risk factors, and the highest ratio between observed and expected prevalence was: "Smoking + Alcohol" (79.0\%; 95\%Cl: 73.8-84.2). Conclusion and implications for practice: The findings show a high prevalence of concurrent risk factors, with aggregation of these in adolescents. Identifying these risk groups may favor early interventions by minimizing exposure and targeting primary prevention strategies in early exposure to risk factors.
\end{abstract}

Keywords: Noncommunicable Diseases; Adolescent; Risk Behavior.

\section{Resumo}

Objetivo: Estimar a prevalência da simultaneidade de fatores de risco para doenças crônicas não transmissíveis e o agregamento não aleatório destes em adolescentes escolares brasileiros. Método: Estudo descritivo, com dados da Pesquisa Nacional de Saúde do Escolar, 2015. Foi estimada a prevalência dos fatores de risco simultâneos: tabagismo, uso de álcool, inatividade física e baixo consumo de frutas e legumes. O agregamento foi verificado quando a razão entre a prevalência observada e a esperada foi superior a 1. As análises foram realizadas no software Stata 15.0. Resultados: A proporção de fatores de risco simultâneos foi maior para quem tinha dois fatores de risco (56,1\%; IC95\%: 55,5-56,6). A combinação de fatores de risco mais prevalente foi "Baixo consumo de frutas e hortaliças + Inatividade física" (66\%; IC95\%: 65,8-66,9). Houve agregamento de fatores de risco, sendo que a maior razão entre a prevalência observada e a esperada foi para: “Tabagismo + Álcool” (79,0; IC95\%: 73,8-84,2). Conclusão e implicações para a prática: Os achados mostram uma elevada prevalência de fatores de risco simultâneos, com agregamento destes em adolescentes. Identificar esses grupos de risco pode favorecer intervenções precoces minimizando a exposição e direcionar estratégias de prevenção primária na exposição precoce à fatores de risco.

Palavras-chave: Doenças Crônicas não Transmissíveis; Adolescente; Comportamento de Risco.

\section{Resumen}

Objetivo: Estimar la prevalencia de la concurrencia de factores de riesgo para enfermedades crónicas no transmisibles y la agregación no aleatoria de éstos en adolescentes escolares brasileños. Método: Estudio descriptivo, con datos de la Investigación Nacional de Salud del Escolar (Pesquisa Nacional de Saúde do Escolar) en 2015. Se estimó la prevalencia de los factores de riesgo simultáneos: tabaquismo, uso de alcohol, inactividad física y bajo consumo de frutas y verduras. La agregación se verificó cuando la razón entre la prevalencia observada y esperada fue superior a 1. Los análisis se realizaron en el software Stata 15.0. Resultados: La proporción de factores de riesgo simultáneos fue mayor para quienes tenían dos factores de riesgo (56,1\%, IC95\%: 55,5-56,6). La combinación de factores de riesgo más prevalente fue "Bajo consumo de frutas y verduras + Inactividad física" (66\%, IC95\%: 65,8-66,9). Se ha producido una agregación de factores de riesgo, y que la mayor razón entre la prevalencia observada y esperada fue para: "Tabaquismo + Alcohol" (79,0; IC95\%: 73,8-84,2). Conclusión e implicaciones para la práctica: Los hallazgos muestran una elevada prevalencia de factores de riesgo simultáneos, con agregación de éstos en adolescentes. Identificar estos grupos de riesgo puede favorecer intervenciones tempranas, minimizando la exposición y direccionar estrategias de prevención primaria en la exposición precoz a factores de riesgo.

Palabras clave: Enfermedades no Transmisibles; Adolescente; Asunción de Riesgos. 


\section{INTRODUCTION}

Noncommunicable Diseases (NCD) account for 41 million deaths annually, which is equivalent to $71 \%$ of all deaths worldwide. Cardiovascular diseases accounted for the majority of deaths from NCDs in 2015 , followed by cancer, respiratory diseases and diabetes. These four disease groups account for more than $80 \%$ of all premature deaths by $\mathrm{NCD}^{1}$ and share four behavioral and modifiable risk factors: inadequate diet, physical inactivity, alcohol and tobacco use ${ }^{2}$.

It is noted that these risk factors usually occur simultaneously ${ }^{3}$ and evidence shows that involvement in multiple risk behaviors is associated with increased risk of chronic disease and mortality compared to involvement in one or no risk behavior ${ }^{4}$.

Currently, health agendas prioritize interventions targeting common risk factors in adults, stimulated by estimates that show that $70 \%$ of premature deaths in adults are largely due to behaviors started in adolescence, such as smoking, obesity, low levels of physical activity and alcohol consumption ${ }^{5}$.

Most studies on the subject treat these risk factors in isolation $^{6-11}$. Research on the simultaneity of risk factors for NCDs, with only adolescents, is scarce and recent in Brazil, having investigated beyond the prevalence of simultaneous risk factors $^{12}$, aggregation ${ }^{13,14}$ and associated factors ${ }^{14,15}$. Although they bring relevant results, these are local studies, not having national representativeness, justifying the relevance of this study.

Results from previous editions of the National School Health Survey (PeNSE - Pesquisa Nacional de Saúde do Escolar) show prevalence of risk behaviors in adolescents in isolation 16 . Nevertheless, there is still no data on the simultaneous prevalence of these risk factors with a representative sample of Brazilian school adolescents.

Estimating the prevalence and non-random aggregation of concurrent risk factors may be useful for health managers and policy makers to recognize groups with similar characteristics based on patterns of risk behavior, targeting prevention strategies, reducing early risk exposure. The purpose of this study was to estimate the prevalence of the risk factors for NCD and the non-random aggregation of these factors in Brazilian school adolescents using data from PeNSE 2015.

\section{METHOD}

This is a cross-sectional, descriptive epidemiological study with secondary data from the $3^{\text {rd }}$ edition of PeNSE 2015, available on the website of the Brazilian Institute of Geography and Statistics (IBGE - Instituto Brasileiro de Geografia e Estatística) (http://www.ibge.gov.br). The target population was school adolescents who attended the 9th year of elementary school and students aged 13 to 17 years who attended the 6th grade of elementary school through the third year of high school, enrolled in the academic year 2015 and regularly attending public schools and private areas located in urban and rural areas throughout the National Territory ${ }^{17,18}$.
The sampling process was done by conglomerates (complex plans), using three stages of selection: in the first one were selected the municipalities or groups of municipalities (Primary Sampling Unit - PSU); in the second, the schools (Secondary Sampling Unit - SSU); and in the third, the classes (Tertiary Sampling Unit - TSU). All the students present on the day of collection in the drawn classes were invited to participate in the research. The sizing of the sample size in each stratum considered a maximum sampling error of approximately $3 \%$, to estimate a $50 \%$ ratio, with a confidence level of $95 \%{ }^{17}$.

Planning resulted in two samples, with different sampling plans. The sample that contemplates the students attending the $9^{\text {th }}$ grade (old $8^{\text {th }}$ grade) of Elementary School was denominated Sample 1; and the one composed of students from 13 to 17 years of age, attending the $6^{\text {th }}$ to $9^{\text {th }}$ year of Elementary School and the $1^{\text {st }}$ to $3^{\text {rd }}$ grade of High School was denominated Sample 2. Sampling was performed so that it could generate population estimates for both samples, in the geographic strata considered. Details of the sampling process, specificities of the two samples and calculation of the PeNSE 2015 sample weights are available in the complete PeNSE 2015 report ${ }^{17}$. The data were collected after contact and dissemination between the State and Municipal Education Offices, with the direction of the selected schools in each municipality and with the parents of the students of the classes chosen to clarify the objectives and procedures of the study.

In this study, the data referring to Sample 1 of the PeNSE 2015 , which had a final sample of 102,072 students, were analyzed. The variables used were:

1. Gender (Male, Female);

2. Age in years (<13 years, $13,14,15,16$ years and over);

3. Race/Color (white, black, yellow, brown and indigenous));

4. Maternal education (None or Incomplete Elementary School, Complete Elementary School/Incomplete High School, Complete High School/Incomplete Higher School, Complete Higher School, Not informed);

5. Alcohol use in the last $\mathbf{3 0}$ days (percentage of schoolchildren who reported drinking a glass or at least one dose of alcoholic beverage at least once in the 30 days prior to the survey, categorized as: "No, none" or "Yes, one or more in the last 30 days") ${ }^{19}$;

6. Tobacco use in the last 30 days (percentage of school adolescents who reported smoking at least once in the 30 days prior to the survey, regardless of frequency and intensity, categorized as: "No, never smoked, no day" or "Yes, one or more days in the last 30 days") ${ }^{19}$;

7. Low consumption of fruits and vegetables (percentage of school adolescents who consumed less than five servings of fruits and vegetables in the last seven days prior to the survey) ${ }^{20}$; 
8. Physical inactivity, as measured by overall estimated physical activity (The overall estimated physical activity refers to the number of days that the students declared to do at least one hour per day of physical activity in the seven days prior to the survey, with the estimated time in minutes were considered as those who counted a time $\geq 300$ minutes and inactive those who counted a time $<300$ minutes) $)^{17,19}$

The dependent variable "Simultaneous risk factor" was generated by the sum of scores of the four factors (alcohol, tobacco use, physical inactivity and inappropriate intake of fruits and vegetables) ranging from 0 to 4 , where "0" represents absence of any of these factors and the other values represent the number of factors simultaneously present. Each variable was categorized as " 0 " to indicate absence and " 1 " to indicate presence.

Statistical analyzes were performed in Stata 15.0 software, considering the complexity of the sampling plan. For this, we used the different weights of the observations that influence the point estimates of parameters of the total population by survey command. The individual proportions of risk factors were stratified by gender and estimates were produced for the population. Pearson's Chi-square test was used to evaluate the difference between groups. A 95\% Confidence Interval (95\% Cl) and a significance level of $5 \%$.

The observed prevalence of the 16 possible combinations of risk factors were estimated. The non-random aggregation of risk factors was verified when the Observed Prevalence (OP) of the combination of factors exceeded the Expected Prevalence (EP). EP of a specific pattern of risk factor aggregation was calculated by multiplying the individual probabilities of each risk factor occurring in the sample. Therefore, it was possible to investigate which combinations were higher or lower than the expected values, assuming that the risk factors occur independently in the study population. The result between the OP ratio for EP (OP/EP) greater than 1 indicates the existence of non-random factors ${ }^{21,22}$.

PeNSE 2015 was approved in the National Ethics Committee in Research - CONEP (Comissão Nacional de Ética em Pesquisa) of the Brazilian Health Board - CNS (Conselho Nacional de Saúde), which regulates and approves health research involving human beings, through the Opinion CONEP 1,006,467, dated 03.30.2015.

\section{RESULTS}

This study analyzed data from Sample 1 of PeNSE 2015 composed of 102,072 individuals. For the purposes of this analysis, a subpopulation was used, considering the observations whose variables of interest for this study had no missing data. Thus, this sample is composed of 99,738 individuals, the majority being female (51.6\%; Cl:50.9-52.2), with 14 years of age (51.2\%;
95\% Cl:50.3 -52.1), mean age 14.3 years (SD: $\pm 0.012, \mathrm{Cl}: 14.2-$ 14.3), brown color (43.1\%,95\% Cl: $42.2-44.0)$ and students of public school (85.3\% Cl: 83.1-87.3). The adolescents whose mothers had no schooling or only the incomplete elementary school corresponded to $24.7 \%$ (95 Cl: $24.0-25.4$ ) and $26.6 \%$ (95\% Cl: 26.0-27.3) did not know inform mother's schooling (Table 1).

The proportion of risk factors isolated was higher for low consumption of fruits and vegetables $(80.6 \% ; 95 \% \mathrm{Cl}: 80.1-81.2)$ and physical inactivity $(79.5 \% ; 95 \% \mathrm{Cl}: 79.0-80.0)$, followed by alcohol consumption (23.8\%, 95\% Cl: 23.2-24.4). The lowest risk factor was tobacco consumption (5.6\%, 95\% Cl: 5.2-5.9). There was a significant difference between genders for alcohol use $(22.5 \%$ for males and $25.1 \%$ for females, $p<0.0001)$ and physical inactivity $(71.7 \%$ for males and $86.9 \%$ for the female $p$ $<0.0001$ ) (Table 1).

Figure 1 shows the proportion of concurrent risk factors: alcohol, tobacco, physical inactivity and low consumption of fruits and vegetables for the total sample and stratified by gender. The highest proportion was two simultaneous risk factors $(56.1 \%$, $95 \% \mathrm{Cl}: 55.5-56.6)$. When comparing by gender, the proportions of two (58.5; 95\%Cl: 57.7-59.3), three (16.6\%, 95\% Cl: $16.0-17.2)$ and four (3.2 (95\% Cl: 2.9-3.6). Simultaneous risk factors were higher for females, with significant difference between groups $(p<0.0001)$.

Figure 2 shows the proportions of simultaneous risk factors by geographical regions of Brazil among female and male adolescents. It was observed that the highest proportions found among the female were for those who had up to two simultaneous risk factors in the five regions, being the proportion of two risk factors in the Northeast (62.7\%) and North (62.5\%), respectively. Among adolescents with three and four risk factors, the highest proportions were found in the South $(22.7 \%$ for 3 and $4.4 \%$ for four risk factors) and in the Southeast (17.1\% for three and 3, 6\% for four simultaneous risk factors).

The highest proportions found among male adolescents were also for those who had two risk factors. However, when comparing by gender, in all regions, the proportions of two and three risk factors were lower among male adolescents, when compared to the female. Among adolescents with four risk factors, the proportions of the Northeast region were similar in both genders. In the North region it was slightly higher among men and, in the other regions, the proportions among the male adolescents were lower than the proportions found among female adolescents.

Table 2 describes the observed and expected prevalence of different combinations of risk factors for NCDs and their aggregations in adolescents. The most prevalent combination was "Low consumption of fruits and vegetables + Physical inactivity" (OP: 66\%, 95\%Cl: 65.8-66.9). All risk factors presented agglomeration, except for "Low consumption of fruits and vegetables + Physical inactivity + Alcohol" (OP/EP: 1.1; 95\% $\mathrm{Cl}$ : 1.0-1.1). It should be noted that the highest prevalence ratios 
Table 1. Distribution of socio-demographic variables and risk factors according to gender. National School Health Survey, 2015.

\begin{tabular}{|c|c|c|c|c|}
\hline \multirow{2}{*}{ Variables } & \multirow{2}{*}{ Total \% (95\%Cl) } & \multicolumn{2}{|c|}{ Gender } & \multirow{2}{*}{$p$ value } \\
\hline & & Male \% (95\%Cl) & Female \% (95\%Cl) & \\
\hline \multicolumn{5}{|l|}{ Age in years } \\
\hline$<13$ & $0.4(0.3-0.5)$ & $0.3(0.2-0.4)$ & $0.5(0.4-0.6)$ & \multirow[t]{5}{*}{$p<0.0001$} \\
\hline 13 & $18.0(17.0-19.0)$ & $15.7(14.7-16.8)$ & $20.1(18.9-21.3)$ & \\
\hline 14 & $51.2(50.2-52.1)$ & $49.0(47.9-50.0)$ & $53.3(52.1-54.4)$ & \\
\hline 15 & $19.6(18.9-20.4)$ & $22.1(21.2-23.1)$ & $17.3(16.6-18.1)$ & \\
\hline 16 and above & $10.8(10.2-11.4)$ & $12.9(12.2-13.6)$ & $8.8(8.2-9.5)$ & \\
\hline \multicolumn{5}{|l|}{ Color or race } \\
\hline White & $36.3(35.2-37.3)$ & $37.6(36.4-38.8)$ & $35.0(33.8-36.3)$ & \multirow[t]{5}{*}{$p<0.0001$} \\
\hline Black & $13.2(12.7-13.8)$ & $15.3(14.7-16.1)$ & $11.3(10.7-11.9)$ & \\
\hline Yellow & $4.1(3.9-4.4)$ & $3.5(3.3-3.9)$ & $4.6(4.3-5.0)$ & \\
\hline Brown & $43.1(42.2-44.0)$ & $40.0(38.9-41.0)$ & $46.1(44.9-47.2)$ & \\
\hline Indigenous & $3.3(3.1-3.5)$ & $3.6(3.6-4.0)$ & $3.0(2.7-3.3)$ & \\
\hline \multicolumn{5}{|l|}{ School Location } \\
\hline Urban & $91.7(90.5-92.9)$ & $92.0(90.7-93.1)$ & $91.6(90.7-93.1)$ & \multirow[t]{2}{*}{$p=0.1625$} \\
\hline Rural & $8.3(7.1-9.5)$ & $8.0(6.9-9.3)$ & $8.4(7.3-9.8)$ & \\
\hline \multicolumn{5}{|l|}{ Geographical Region } \\
\hline North & $9.6(9.1-10.1)$ & $9.6(9.1-10.1)$ & $9.6(9.1-10.2)$ & \multirow[t]{5}{*}{$p<0.0001$} \\
\hline Northeast & $27.7(26.7-28.8)$ & $26.4(25.3-27.5)$ & $29.0(27.8-30.2)$ & \\
\hline Southeast & $43.4(42.0-44.9)$ & $44.4(42.8-46.0)$ & 42.5 (40.9-44.1) & \\
\hline South & $11.8(11.2-12.5)$ & $12.0(11.4-12.8)$ & 11.6 (10.9-12.4) & \\
\hline Center-West & 7.5 (7.1-7.9) & $7.6(7.2-8.1)$ & $7.3(6.9-7.8)$ & \\
\hline \multicolumn{5}{|l|}{ Maternal schooling } \\
\hline Complete Higher Education & $13.4(12.5-14.4)$ & $14.2(13.1-15.3)$ & $12.7(11.7-13.7)$ & \multirow[t]{5}{*}{$p<0.0001$} \\
\hline Complete High School/Incomplete Higher Education & $22.7(22.0-23.3)$ & $22.9(22.1-23.7)$ & $22.5(21.7-23.4)$ & \\
\hline Complete Elementary School/Incomplete High School & $12.6(12.2-13.0)$ & $12.6(12.1-13.2)$ & $12.6(12.0-13.2)$ & \\
\hline None/Incomplete Elementary School & $24.7(24.0-25.4)$ & $22.8(21.9-23.7)$ & $26.4(25.6-27.3)$ & \\
\hline Do not know how to inform & $26.6(26.0-27.3)$ & $27.5(26.7-28.4)$ & $25.8(25.0-26.6)$ & \\
\hline \multicolumn{5}{|l|}{ Individual Risk Factors } \\
\hline Alcohol & $23.8(23.2-24.4)$ & $22.5(21.7-23.3)$ & $25.1(24.3-25.9)$ & $p<0.0001$ \\
\hline Tobacco & $5.6(5.2-5.9)$ & $5.8(5.3-6.3)$ & $5.3(4.9-5.8)$ & $p=0.1497$ \\
\hline Physical inactivity & $79.5(79.0-80.0)$ & $71.7(71.0-72.5)$ & $86.9(86.3-87.4)$ & $p<0.0001$ \\
\hline Low consumption of fruits and vegetables & $80.6(80.1-81.2)$ & $80.5(79.8-81.2)$ & $80.8(80.0-81.5)$ & $p=0.5173$ \\
\hline
\end{tabular}

Source: National School Health Survey, 2015. * 95\% Cl: 95\% Confidence Interval.

observed and expected were for the following combinations: "Smoking + Alcohol" (OP/EP: 79.0; 95\%Cl: 73.8-84.2); "Low consumption of fruits and vegetables + Smoking + Alcohol" (OP/EP: 15.9; 95\%Cl: 14.7-17.1) and "Physical inactivity + Smoking + Alcohol" (15.3; 95\%Cl: 14.2-16.5).

\section{DISCUSSION}

This study showed the isolated and simultaneous occurrence of the four main risk factors for NCD and the aggregation of these factors in a representative sample of Brazilian school adolescents, with data from the PeNSE 2015. 
Figure 1. Proportion of simultaneous risk factors for NCD in brazilian school adolescents. National School Health Survey, 2015.

Source: National School Health Survey, 2015.

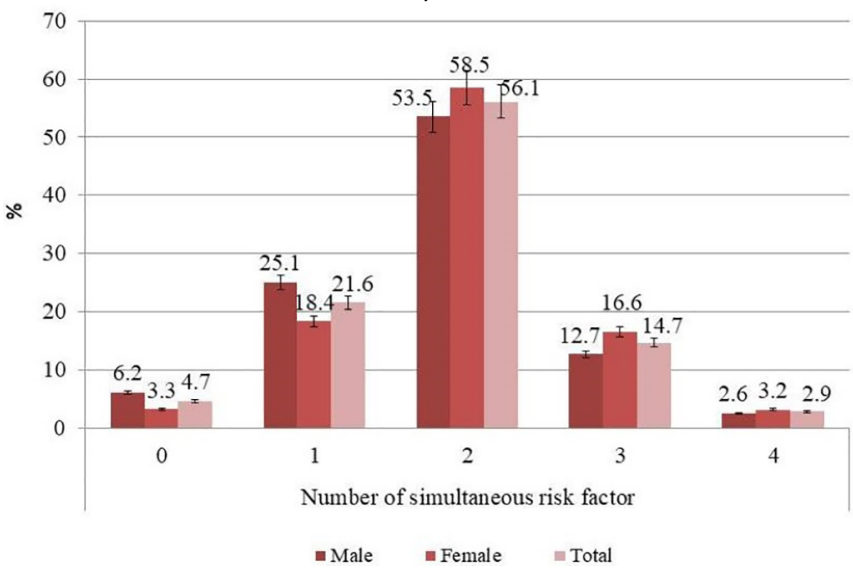

Figure 2. Proportion of simultaneous risk factors for NCD in adolescents by geographic region. National School Health Survey, 2015.

Source: National School Health Survey, 2015.

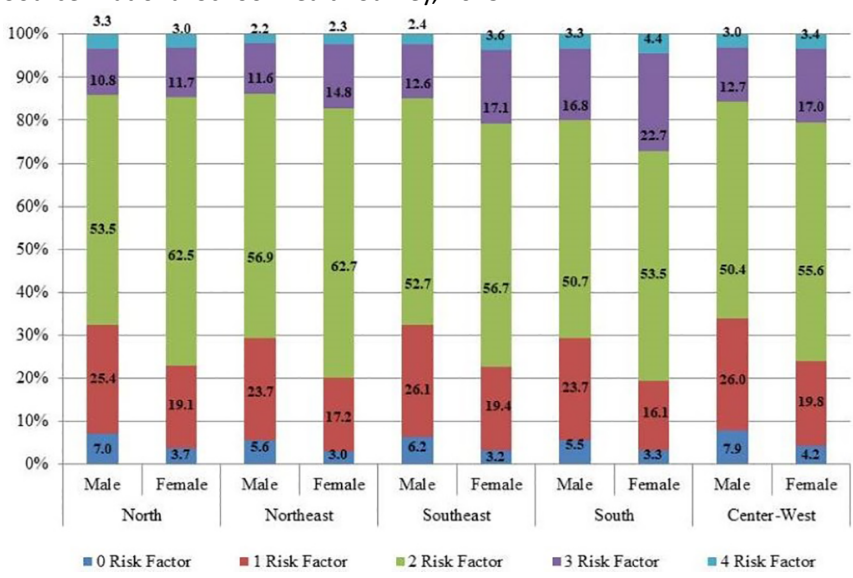

The proportion of risk factors isolated, such as low consumption of fruits and vegetables and physical inactivity, was high. When examining the proportion of multiple risk factors, more than half had at least two factors. The most prevalent risk factors combination was the low consumption of fruits and vegetables with physical inactivity. Only $4.7 \%$ of adolescents did not present any factor.

Comparability with other similar studies is restricted, since the inclusion of risk factors was varied, including the fact that these studies are of local scope. International surveys on the simultaneity of risk factors in different population groups were carried out using population surveys, whose indicators used were the same as in this study: smoking, alcohol consumption, physical inactivity and poor diet in fruits and vegetables. These studies found the following prevalence for two or more concurrent risk factors: $68 \%$ in people aged 16 years or older in England; $34 \%$ in men and $26 \%$ in women aged 25 years or more in Switzerland ${ }^{23}$ and $39.2 \%$ in men; and $24.6 \%$ in adult women in Finland ${ }^{24}$.
Regional differences were also observed in this study, and in the North and Northeast regions, greater proportions were found for those who had two risk factors in both genders. The adolescents with the highest proportions of three and four risk factors resided in the South and Southeast regions. A metaanalysis study showed that the prevalence of two and three simultaneous risk factors in adolescents in middle- and lowincome countries worldwide was $40 \%$ and $10 \%$, respectively, and varied according to geographic region studied ${ }^{19}$. Authors failed to explain the regional differences found in the study but believe that social norms and cultures can shape adolescents' health behavior and political and economic factors can influence those choices, and it is relevant to explain these differences ${ }^{19}$.

The high prevalence of adolescents with two or more simultaneous risk factors described in our results has important implications, considering that evidence from longitudinal studies on health risk behaviors shows changes in behaviors related to physical activity, fruit intake, smoking and drunkenness according to the prevailing social norms about these behaviors at different ages, from adolescence to adulthood ${ }^{25}$. It should be emphasized that the behaviors can vary throughout the adolescence, being able to be a mix of healthy and unhealthy behaviors ${ }^{26}$.

The highest prevalence of two, three and four risk factors found among women were reported in a study with adults. However, it cannot be said that women would be at greater risk than men because there is no clear explanation for these differences, which requires further investigation. It should be noted that many of the studies on concurrent risk factors use different risk indicators, analytical techniques and cut-off points and are therefore inconclusive about which group would be at greatest risk ${ }^{21}$

The most prevalent combination in this study was "Low consumption of fruits and vegetables + Physical inactivity". A systematic review study synthesized evidence from different countries and showed that the simultaneous occurrence of risk factors and the most common combinations found in adolescents differ from those found in adults ${ }^{27}$.

Findings also showed that the most prevalent aggregations were "Smoking + Alcohol", "Low consumption of fruits and vegetables + Smoking + Alcohol" and "Physical inactivity + Smoking + Alcohol". There is evidence that in adults the use of alcohol and tobacco tends to be added ${ }^{27}$. In England, we found aggregations of "Smoking, alcohol consumption and inadequate consumption of fruits and vegetables" and "Physical inactivity and inadequate consumption of fruits and vegetables" in a population older than 16 years ${ }^{21}$. In adolescents, studies showed associations between inadequate fruit and vegetable intake and low physical activity, but did not show aggregation patterns, since they were not the focus of investigations ${ }^{28,29}$. Thus, there is a limitation in the comparability with studies conducted in other countries to verify the existence of an association of these same risk factors in adolescents. 
Table 2. Prevalence and aggregation of simultaneous risk factors and ratios between observed and expected prevalence. National School Health Survey, 2015.

\begin{tabular}{|clccc}
\hline RF number & Risk Factors combination & OP & EP & OP/EP\# (95\%CI) \\
\hline 4 & $\begin{array}{l}\text { Low consumption of fruits and vegetables + Physical inactivity + Smoking } \\
\text { + Alcohol }\end{array}$ & 2.9 & 0.93 & $3.1(2.9-3.4)$ \\
\hline 3 & Physical inactivity + Smoking + Alcohol & 3.4 & 0.22 & $15.3(14.2-16.5)$ \\
\hline 3 & Low consumption of fruits and vegetables + Smoking + Alcohol & 3.7 & 0.23 & $15.9(14.7-17.1)$ \\
\hline 3 & Low consumption of fruits and vegetables + Physical inactivity + Alcohol & 15.5 & 14.6 & $1.1(1.0-1.1)$ \\
\hline 3 & Low consumption of fruits and vegetables + Physical inactivity + Smoking & 3.8 & 2.95 & $1.3(1.2-1.4)$ \\
\hline 2 & Smoking + Alcohol & 4.3 & 0.05 & $79.0(73.8-84.2)$ \\
\hline 2 & Physical inactivity + Alcohol & 18.3 & 3.43 & $5.4(5.2-5.5)$ \\
\hline 2 & Physical inactivity + Smoking & 4.3 & 0.69 & $6.3(5.8-6.7)$ \\
\hline 2 & Low consumption of fruits and vegetables + Alcohol & 19.5 & 3.65 & $5.3(5.2-5.5)$ \\
\hline 2 & Low consumption of fruits and vegetables + Smoking & 4.7 & 0.74 & $6.5(6.0-6.9)$ \\
\hline 2 & Low consumption of fruits and vegetables + Physical inactivity & 66.0 & 46.3 & $1.4(1.4-1.5)$ \\
\hline 1 & Alcohol & 23.8 & 0.86 & $27.8(27.1-28.5)$ \\
\hline 1 & Smoking & 5.6 & 0.17 & $32.1(30.0-34.1)$ \\
\hline 1 & Physical inactivity & 79.5 & 10.9 & $7.3(7.2-7.4)$ \\
\hline 1 & Low consumption of fruits and vegetables & 80.6 & 11.6 & $7.0(6.9-7.1)$ \\
\hline 0 & No risk factor & 4.7 & 2.71 & $1.7(1.6-1.8)$ \\
\hline
\end{tabular}

Source: National School Health Survey, 2015. * RF: Risk Factors; OP: Observed Prevalence; EP: Expected Prevalence; * OP/EP: Ratio between observed and expected prevalence; The ratio calculation was done considering the sample weights. Therefore, the result may differ from the simple ratio calculation. $95 \%$ Cl: 95\% Confidence Interval.

It is noteworthy that in all the most prevalent risk factor aggregations, smoking and alcohol were present. Results from the Pesquisa Nacional Longitudinal de Crianças e Jovens (greely translated as National Longitudinal Children and Adolescents Survey), with a representative sample of Canadian children and adolescents, showed aggregation of tobacco and alcohol and, except for the combination of physical inactivity, sedentary behavior and high Body Mass Index (BMI), all combinations of three and four behaviors that were included smoking and alcohol ${ }^{30}$. Although authors have worked with different risk factors (physical inactivity, sedentary behavior, smoking, alcohol and high $\mathrm{BMI}$ ), the results corroborate our findings about the importance of the addition of "Smoking + Alcohol".

As the use of alcohol is socially accepted, many adolescents start using it early and remain in use in adulthood. There is a positive relationship between alcohol and tobacco, suggesting that alcohol stimulates tobacco use. It is believed that this is because these behaviors are more influenced by cultural aspects $^{31}$. This may not be enough, but explain in part the fact that the observed prevalence of the combination "Smoking + Alcohol" was much higher than expected when compared to other combinations.
Among the limitations of this study, we cite the bias of social desirability, since adolescents can provide answers that underestimate the prevalence of risk behaviors, aiming to show that they adopt socially accepted behaviors. These results have as a strong point: rigor of the methods used in PeNSE, the fact of having a minimum non-response rate and its national representativeness.

\section{CONCLUSIONS}

The results found in this study show a high prevalence of simultaneous risk factors in Brazilian adolescents and, therefore, indicate the need for preventive actions with strategies that include behavioral changes throughout the life cycle, since behaviors are initiated in the childhood and may persist in adolescence and adulthood.

This study has important implications for the practice, since knowing the prevalence of the main risk factors for NCDs and their clusters in adolescents may direct primary prevention strategies, behavior change and the promotion of a healthy transition between the adolescent and adulthood phase. 


\section{FINANCIAL SUPPORT}

This study was funded by the Coordination for the Improvement of Higher Level Personnel - CAPES (Coordenação de Aperfeiçoamento de Pessoal de Nível Superior) (Doctorate Scholarship) and Ministry of Health, Agreement 86, Process 25000.192056/2014-16.

\section{REFERENCES}

1. GBD 2015 Risk Factors Collaborators. Global, regional, and national comparative risk assessment of 79 behavioural, environmental and occupational, and metabolic risks or clusters of risks, 1990-2015: a systematic analysis for the Global Burden of Disease Study 2015. Lancet [Internet]. 2016 oct; [citado 2018 sep 20]; 388(10053):1659-724. Disponível em: https://www.ncbi.nlm.nih.gov/pubmed/27733284

2. Ezzati M, Riboli E. Behavioral and dietary risk factors for noncommunicable diseases. N Engl J Med [Internet]. 2013 sep; [citado $2018 \mathrm{sep}$ 20]; 369:954-64. Disponível em: https://www.nejm.org/doi/full/10.1056/ NEJMra1203528

3. GBD 2016 Risk Factors Collaborators. Global, regional, and national comparative risk assessment of 84 behavioural, environmental and occupational, and metabolic risks or clusters of risks, 1990-2016: a systematic analysis for the Global Burden of Disease Study 2016. Lancet [Internet]. 2017 sep; [citado 2018 sep 20]; 390(10100):13451422. Disponível em: https://www.thelancet.com/journals/lancet/article/ PIIS0140-6736(17)32366-8/fulltext

4. Meader N, King K, Wright K, Graham HM, Petticrew M, Power C et al. Multiple Risk Behavior Interventions: Meta-analyses of RCTs. Am J Prev Med [Internet]. 2017 jul; [citado 2018 sep 20]; 53(1):e19-e30. Disponível em: https://www.ncbi.nlm.nih.gov/pubmed/28258777

5. Sawyer SM, Afifi RA, Bearinger LH, Blakemore SJ, Dick B, Ezeh AC, et al. Adolescence: a foundation for future health. Lancet [Internet]. 2012 apr; [citado 2018 sep 20]; 379(9826):1630-40. Disponível em: https:// www.ncbi.nlm.nih.gov/pubmed/22538178

6. Hallal PC, Knuth AG, Cruz DKA, Mendes MI, Malta DC. Prática de atividade física em adolescentes brasileiros. Ciênc Saúde Coletiva [Internet]. 2010 oct; [citado 2018 sep 20]; 15(Suppl 2):303542. Disponível em: http://www.scielo.br/scielo.php?script=sci_ isoref\&pid=S1413-81232010000800008\&lng=en\&tlng=pt

7. Araújo C, Toral N, Silva ACF, Velásquez-Melendez G, Dias AJR. Estado nutricional dos adolescentes e sua relação com variáveis sociodemográficas: Pesquisa Nacional de Saúde do Escolar (PeNSE), 2009. Ciênc Saúde Coletiva [Internet]. 2010 oct; [citado $2018 \mathrm{sep}$ 20]; 15(Suppl 2):3077-84. Disponível em: http://www.scielo.br/scielo. php?script=sci_arttext\&pid=S1413-81232010000800012

8. Tavares LF, Castro IRR, Levy RB, Cardoso LO, Claro RM. Padrões alimentares de adolescentes brasileiros: resultados da Pesquisa Nacional de Saúde do Escolar (PeNSE). Cad Saúde Pública [Internet]. 2014 dec; [citado 2018 sep 21]; 30(12):1-13. Disponível em: http://www. scielo.br/scielo.php?pid=S0102-311X2014001202679\&script=sci arttext\&ting=pt

9. Barreto SM, Giatti L, Oliveira-Campos M, Andreazzi MA, Malta DC. Experimentação e uso atual de cigarro e outros produtos do tabaco entre escolares nas capitais brasileiras (PeNSE 2012). Rev Bras Epidemiol [Internet]. 2014; [citado 2018 sep 21]; 7(Suppl 1):62-76. Disponível em: http://www.scielo.br/scielo.php?pid=S1415790X2014000500062\&script=sci_arttext\&tlng=pt

10. Malta DC, Mascarenhas MDM, Porto DL, Barreto SM, Morais Neto OL. Exposição ao álcool entre escolares e fatores associados. Rev Saúde Pública [Internet]. 2014 feb; [citado 2018 sep 21]; 48(1):52-62. Disponível em: http://www.scielo.br/scielo.php?script=sci_arttext\&pid $=$ S0034-89102014000100052
11. Reis TG, Oliveira LCM. Padrão de consumo de álcool e fatores associados entre adolescentes estudantes de escolas públicas em município do interior brasileiro. Rev Bras Epidemiol [Internet]. 2015 mar; [citado 2018 sep 21]; 18(1):13-24. Disponível em: http://www.scielo.br/scielo. php?script=sci_arttext\&pid=S1415-790X2015000100013\&Ing=en

12. Brito ALS, Hardman CM, Barrosa MVG. Prevalência e fatores associados à simultaneidade de comportamentos de risco à saúde em adolescentes. Rev Paul Pediatr [Internet]. 2015 dez; [citado 2018 sep 21]; 33(4):423-30. Disponível em: http://www.scielo.br/scielo. php?script=sci_arttext\&pid=S0103-05822015000400009\&lng=pt

13. Silva KS, Lopes AS, Vasques DG, Costa FF, Silva RCR. Simultaneidade dos fatores de risco para doenças crônicas não transmissíveis em adolescentes: prevalência e fatores associados. Rev Paul Pediatr [Internet]. 2012 sep; [citado 2018 sep 22]; 30(3):338-45. Disponíve em: http://www.scielo.br/scielo.php?script=sci_arttext\&pid=S010305822012000300006\&lng=en

14. Tassitano RM, Dumith SC, Chica DAG, Tenório MCM. Aggregation of the four main risk factors to non-communicable diseases among adolescents. Rev Bras Epidemiol [Internet]. 2014 jun; [citado 2018 sep 21]; 17(2):465-78. Disponível em: http://www.scielo.br/scielo. php?script=sci_arttext\&pid=S1415-790X2014000200465\&lng=en

15. Nunes HEG, Gonçalves ECA, Vieira JAJ, Silva DAS. Clustering of Risk Factors for Non-Communicable Diseases among Adolescents from Southern Brazil. PloS ONE [Internet]. 2016 jul; [citado $2018 \mathrm{sep}$ 21]; 11(7):e0159037. Disponível em: https://journals.plos.org/plosone/ article?id=10.1371/journal.pone.0159037

16. Malta DC, Andreazzi MAR, Oliveira-Campos M, Andrade SSCA, Sá NNB Moura $L$ et al. Tendência dos fatores de risco e proteção de doenças crônicas não transmissíveis em adolescentes, Pesquisa Nacional de Saúde do Escolar (PeNSE 2009 e 2012). Rev Bras Epidemiol [Internet] 2014; [citado 2018 sep 22]; Disponível em: http://www.scielo.br/scielo. php?script=sci_arttext\&pid=S1415-790X2014000500077\&lng=pt

17. Ministério da Saúde (BR). Instituto Brasileiro de Geografia e Estatística IBGE. Diretoria de Pesquisas. Coordenação de População e Indicadores Sociais. Pesquisa Nacional de Saúde do Escolar:2015. Rio de Janeiro: IBGE; 2016. p.132.

18. Oliveira MM, Campos MO, Andreazzi MAR, Malta DC. Características da Pesquisa Nacional de Saúde do Escolar - PeNSE. Epidemio Serv Saude [Internet]. 2017 sep; [citado 2018 sep 22]; 26(3):603 16. Disponível em: http://www.scielo.br/scielo.php?script=sci_ arttext\&pid=S2237-96222017000300605\&Ing=en

19. Caleyachetty R, Echouffo-Tcheugui JBE, Tait CA, Schilsky S, Forrester T, Kengne AP. Prevalence of behavioural risk factors for cardiovascular disease in adolescents in low-income and middle-income countries: an individual participant data meta-analysis. Lancet Diabetes Endocrinol [Internet]. 2015 jul; [citado 2018 sep 22]; 3(7):535-44. Disponíve em: https://www.thelancet.com/journals/landia/article/PIIS22138587(15)00076-5/fulltext

20. Levy RB, Castro IRR, Cardoso LO, Tavares LF, Sardinha LMV, Gomes FS, et al. Consumo e comportamento alimentar entre adolescentes brasileiros: Pesquisa Nacional de Saúde do Escolar (PeNSE), 2009. Ciênc Saúde Coletiva [Internet]. 2010 oct; [citado 2018 dez 28] 15 (Suppl 2):3085-97. Disponível em: http://www.scielo.br/scielo. php?script=sci_arttext\&pid=S1413-81232010000800013\&lng=enhttp:// dx.doi.org/10.1590/S1413-81232010000800013

21. Poortinga $\mathrm{W}$. The prevalence and clustering of four major lifestyle risk factors in an English adult population. Prev Med [Internet]. 2007 feb [citado 2018 sep 22]; 44(2):124-8. Disponível em: https://www.sciencedirect.com/science/article/pii/S0091743506004208?via\%3Dihub

22. Schuit AJ, van Loon AJ, Tijhuis M, Ocke M. Clustering of lifestyle risk factors in a general adult population. Prev Med [Internet]. 2002 sep; [citado 2018 sep 21]; 35(3):219-24. Disponível em: https://www.sciencedirect. com/science/article/pii/S0091743502910649?via\%3Dihub 
23. Chiolero A, Wietlisbach V, Ruffieux C, Paccaud F, Cornuz J. Clustering of risk behaviors with cigarette consumption: A population-based survey. Prev Med [Internet]. 2006 may; [citado 2018 sep 21]; 42(5):34853. Disponível em: https://www.sciencedirect.com/science/article/pii/ S0091743506000399?via\%3Dihub

24. Laaksonen $M$, Prättälä R, Karisto $A$. Patterns of unhealthy behaviour in Finland. Eur J Public Health [Internet]. 2001 sep; [citado 2018 sep 22]; 11(3):294-300. Disponível em: https://www.researchgate.net/ publication/11766109_Patterns_of_unhealthy_behaviour_in_Finland

25. Wiium N, Breivik K, Wold B. Growth Trajectories of Health Behaviors from Adolescence through Young Adulthood. Int J Environ Res Public Health [Internet]. 2015 oct; [citado 2018 sep 22]; 12(11):13711-29. Disponivel em: https://www.mdpi.com/1660-4601/12/11/13711

26. Lawrence EM, Mollborn S, Hummer RA. Health lifestyles across the transition to adulthood: Implications for health. Soc Sci Med [Internet]. 2017 nov; [citado 2018 sep 23]; 193:23-32. Disponível em: https://www. sciencedirect.com/science/article/abs/pii/S0277953617305853

27. Meader N, King K, Moe-Byrne T, Wright K, Graham H, Petticrew M, et al. A systematic review on the clustering and co-occurrence of multiple risk behaviours. BMC Public Health [Internet]. 2016 jul; [citado 2018 sep 23]; 16:657. Disponível em: https://bmcpublichealth.biomedcentral. com/articles/10.1186/s12889-016-3373-6
28. Sanchez A, Norman GJ, Sallis JF, Calfas KJ, Cella J, Patrick K. Patterns and correlates of physical activity and nutrition behaviors in adolescents. Am J Prev Med [Internet]. 2007 feb; [citado $2018 \mathrm{dez}$ 28]; 32(2):124-30. Disponível em: https://www.ncbi.nlm.nih.gov/pmc/ articles/PMC1913476/

29. Pearson N, Atkin A, Biddle S, Gorely T, Edwardson C. Patterns of adolescent physical activity and dietary behaviours. Int J Behav Nutr Phys Act [Internet]. 2009 jul; [citado 2018 dez 28]; 6:45. Disponível em: https://www.ncbi.nlm.nih.gov/pubmed/19624822

30. Alamian A, Paradis G. Clustering of chronic disease behavioral risk factors in Canadian children and adolescents. Prev Med [Internet] 2009 may; [citado 2018 dez 28]; 48(5):493-9. Disponível em: https:// www.ncbi.nlm.nih.gov/pubmed/19254742

31. Leão AS, Moura Soares NM, Gonçalves ECDA, Silva DAS, Silva RJS, Thomazzi SM. Simultaneous Health Risk Behaviors in Adolescents Associated with Higher Economic Class in the Northeast of Brazil. Sci World J [Internet]. 2017 jul; [citado 2018 sep 22]; 1-7. Disponível em: https://www.ncbi.nlm.nih.gov/pmc/articles/PMC5549486/pdf/ TSWJ2017-3587567.pdf

a Article extracted from the doctoral thesis "Simultaneous risk factors for noncommunicable chronic diseases on Brazilian school teenagers", defended in 2019 , in the Graduate Program in Nursing, Federal University of Minas Gerais. 